\title{
Correlation Between Frequency of Seizure and Cognitive Development Levels in Children with Drug Resistant Epilepsy
}

\author{
Ni Luh Sukma Pratiwi Murti*, Gusti Ngurah Suwarba, Gusti Ayu Trisna Windiani \\ Department of Child Health, Medical Faculty of Udayana University, Sanglah Hospital, Denpasar, Indonesia \\ Email address: \\ sukma.pratiwi2509@gmail.com (Ni L. S. P. Murti) \\ ${ }^{*}$ Corresponding author \\ To cite this article: \\ Ni Luh Sukma Pratiwi Murti, Gusti Ngurah Suwarba, Gusti Ayu Trisna Windiani. Correlation Between Frequency of Seizure and Cognitive \\ Development Levels in Children with Drug Resistant Epilepsy. American Journal of Pediatrics. Vol. 6, No. 3, 2020, pp. $353-356$. \\ doi: 10.11648/j.ajp.20200603.40
}

Received: July 15, 2020; Accepted: July 29, 2020; Published: August 25, 2020

\begin{abstract}
Epilepsy, if not treated properly, can develop into refractory epilepsy or drug-resistant epilepsy. This type of epilepsy does not respond perfectly to the anti-epileptic drugs given. Drug-resistant epilepsy causes ischemia in neuron cells in the brain. Drug resistant epilepsy can cause impaired cognitive function, especially in children who are in the golden age. Epilepsy prevalence from various studies ranged from 1.5 to 31/1000 population. Epilepsy cases in Indonesia are predicted to range from 0.7 to $1 \%$ of the population in Indonesia or range from 1.5 to 2 million people. To determine correlation between the frequency of seizures with the level of cognitive development in children with drug resistant epilepsy. A cross sectional correlation study was carried out in 41 children with drug resistant epilepsy to determine cognitive values in drug resistant epileptic children. The sample was chosen from an affordable population by non-random sampling or consecutive sampling. The research hypothesis is there is a level of cognitive development in children aged 6 to 68 months with drug resistant epilepsy. Calculation of research subjects used the formula for correlative research. Data analysis was performed by Saphiro-Wilk data normality test, correlation analysis used Coefficient Lambda. Results were significant if the value of $\mathrm{p}<0.05$. The results of this study found female subject $26(63.4 \%)$. There were 16 subjects $(39 \%)$ well nourished. diagnosis age of epilepsy< $<1$ year $15(37 \%)$. Number of seizure periods $<10$ times $12(29 \%)$. The number of anti-seizure medication were 2 drugs 27 subject (65\%). Abnormal 1 EEG results were 8 subjects (19.5\%). The Mullen Scale test results are below average 38 subject $(97.2 \%)$. Strong correlation of seizure frequency $\geq 10$ times was statistically significant to the level of cognitive development in children with epilepsy with $\mathrm{r} 0.783$ with a p value was 0.00 . Frequency of seizure $43.3 \%$ influenced cognitive development level. Conclusion, the frequency of seizures has a positive strong correlation to the level of cognitive development.
\end{abstract}

Keywords: Seizure Frequency, Drug Resistant Epilepsy, Level of Cognitive Development

\section{Introduction}

Drug resistant epilepsy defined as a failure of adequate trials of two tolerated and appropriately chosen antiepileptic drugs (AED) schedules (whether as monotherapies or in combination) to achieve seizure freedom. Refractory epilepsy or drug resistant epilepsy is often caused by resistance to antiepileptic drugs. The mechanisms occur is still unclear [1]. Epileptic patients who do not successfully controlled by antiepileptic drugs can be considered experienced drug resistant epilepsy. Golden age is an important period for an optimal growth and development of children. During 0 to 5 years age, children's brain going to have formation of nerve cells. When the child suffered epilepsy during the golden age will the formation of the brain's nerve cells will disturb. Disruption of the formation of nerve cells that causes a decrease in cognitive function in children who have an impact on the quantity and the quality of life of the child itself [2].

Mullen scale can be used to evaluate cognitive level in 
children. Measurement result divided into above average (very high, above average and average) and below average (below average and very low). Mullen has been evaluated and validated as a tool to evaluate cognitive level in children [3]. Previous research in 2015 found that frequency of seizure $>10$ times in general epilepsy children significant with cognitive level. This study also found cognitive impairment $47 \%$ in children age 12 until 68 months [4]. Research about correlation between frequency of seizure and cognitive development levels in children with drug resistant epilepsy has never been carried out in Indonesia, so a study is needed.

\section{Methods}

Cross-sectional study in was conducted to prove the correlation between frequency of seizure and cognitive development levels in children with drug resistant epilepsy. This study was conducted in pediatric ward/ polyclinic Sanglah Hospital Denpasar starting from February 2016 until August 2018. The inclusion criteria in this study consisted of children from 6 until 68 months with drug resistant epilepsy, still got antiepileptic drugs, parent agreed to participate in this study (evidenced by signing the informed consent). Exclusion criteria included unwilling to joined the study, children with major congenital anomaly, children with brain infection or brain disease such as tumors, brain injury.

The research sample was taken by consecutive sampling method. Data analysis in this study consisted of descriptive statistical analysis and correlation analysis. The statistical test used in the correlation analysis is Coefficient Lambda and Coefficient Determination. The correlation size obtained was adjusted $r$ and $R^{2}$, statistically significant with $p$ value $<0.05$. All data were entered and analyzed using SPSS version 23. This study was declared ethically feasible, with ethical clearance published by the Research Ethics Committee of the Faculty of Medicine Udayana University/Sanglah Hospital.

\section{Result}

Total subject enrolled in this study was 41 subjects. The basic characteristic of the study sample shown in Table 1. From the data presented in Table 1, median of age was 4 years. Total female subject was 26 (63.4\%). Well-nourished subject was 16 (39\%). Diagnosis age of epilepsy $<1$ year $15(37 \%)$. Number of seizure periods $<10$ times 12 (29\%). The number of anti-seizure medication were 2 drugs 27 subject (65\%). Abnormal 1 EEG results were 8 subjects (19.5\%). The test results are below average 38 subjects (97.2\%). analysis with Coefficient Lambda and Coefficient
Determination to get the strength of correlation and the magnitude of correlation. The result shown in Table 2. Correlation analysis by Coefficient Lambda shown positive strong correlation between frequency of seizure and cognitive development levels in children with drug resistant epilepsy with r 0.793 and p value 0.00. Correlation Determination analysis revealed that frequency of seizure influenced cognitive development levels with $\mathrm{R}^{2} 43.3 \%$.

Table 1. Characteristics of subjects.

\begin{tabular}{|c|c|}
\hline Characteristics & $n=41$ \\
\hline Age, median & 4 \\
\hline \multicolumn{2}{|l|}{ Sex, n, \% } \\
\hline Male & $15(36,6)$ \\
\hline Female & $26(63.6)$ \\
\hline \multicolumn{2}{|c|}{ Nutritional status, n, \% } \\
\hline Well nourish & $16(39)$ \\
\hline Mild malnutrition & $22(53.7)$ \\
\hline overweight & $2(4.9)$ \\
\hline \multicolumn{2}{|c|}{ Onset of epilepsy, n, \% } \\
\hline$\geq 1$ year old & $26(63)$ \\
\hline$<1$ year old & $15(37)$ \\
\hline \multicolumn{2}{|c|}{ Frequency of seizure, $n, \%$} \\
\hline$<10$ & $12(29,3)$ \\
\hline$\geq 10$ & $29(70.7)$ \\
\hline \multicolumn{2}{|c|}{ Antiepileptic drugs, n, \% } \\
\hline 2 drugs & $27(65,9)$ \\
\hline 3 drugs & $14(34.1)$ \\
\hline \multicolumn{2}{|l|}{ EEG result, $n, \%$} \\
\hline Abnormal 1 & $8(19.5)$ \\
\hline Abnormal 2 & $33(80.5)$ \\
\hline \multicolumn{2}{|c|}{ Father education, $n, \%$} \\
\hline Middle & $5(12.2)$ \\
\hline High & $36(87.8)$ \\
\hline \multicolumn{2}{|c|}{ Mother education, $n, \%$} \\
\hline Low & $1(2.4)$ \\
\hline Middle & $14(34.1)$ \\
\hline High & $26(63.4)$ \\
\hline \multicolumn{2}{|c|}{ Father occupation, n, \% } \\
\hline Civil servant & $8(19.5)$ \\
\hline Self employe & $25(61)$ \\
\hline Entrepreneur & $8(19.5)$ \\
\hline \multicolumn{2}{|c|}{ Mother occupation, n, \% } \\
\hline Civil servant & $2(4.9)$ \\
\hline Self employe & $8(19.5)$ \\
\hline Entrepreneur & $7(17.1)$ \\
\hline Others & $24(58.5)$ \\
\hline \multicolumn{2}{|l|}{ Mullen result, n, \% } \\
\hline Above average & $3(7.3)$ \\
\hline Below average & $38(92.7)$ \\
\hline
\end{tabular}

Table 2. Correlation analysis frequency of seizure and cognitive development level.

\begin{tabular}{|c|c|c|c|c|c|}
\hline \multirow{2}{*}{ Variable } & \multicolumn{2}{|l|}{ Cognitive development level } & \multirow[t]{2}{*}{$\mathbf{r}$} & \multirow[t]{2}{*}{$\mathbf{R}^{2}$} & \multirow[t]{2}{*}{$P$ value } \\
\hline & Below average & Above average & & & \\
\hline \multicolumn{6}{|c|}{ Frequency of seizure, $\mathrm{n}(\%)$} \\
\hline$<10$ times & $9(75)$ & $3(25)$ & 0.783 & $43.3 \%$ & 0.000 \\
\hline$\geq 10$ times & $29(100)$ & $0(0.0)$ & & & \\
\hline
\end{tabular}




\section{Discussion}

Subjects in this study consist of $5(36.6 \%)$ male and 26 (63.4\%) female subjects. Previous study had different result, where male had a higher risk of suffering epilepsy. Suwarba in 2011 claimed that a study of 276 epilepsy cases found male (56.9\%) than female (43.1\%) [5]. Different result caused by the different of inclusion criteria. In this research, only took drug resistant epilepsy as a subject. Onset of epilepsy found bigger in children $\geq 1$ years. This finding concordance with Camfield in 2012 where the incidence of epilepsy in the first year of life was 100.000 and increased to $40-50$ cases per 100.000 children between 1-10 years age children, and decreased about 20 cases per 100.000 children in adolescent phase [6].

Abnormal 2 EEG result was $80.5 \%$ in this study. Epileptiform wave in abnormal EEG result indicates a hypofunction and it's shown a severe brain damage. EEG examination in this study not performed in 24 hours after seizure attack so it can't reflect the actual condition. Video-EEG monitoring is needed to perform actual condition. This study similar to other study which reveals that various factors can be related to cognitive and epilepsy including frequency of seizure [7, 12]. Previous study found that progressive cognitive in children with epilepsy influenced by frequent seizures, younger onset of seizures, antiepileptic drugs, resistance of antiepileptic drugs. In this study found frequency of seizure $\geq 10$ times has a positive strong correlation to the level of cognitive development.

There are 3 main causes that contribute to the onset and progressivity of the disease: genetic factors, growth impairment or CNS malformation, brain injury. Brain plasticity in the babies and children are more susceptible to seizures and can causes damage to the neurons $[8,11,12,14]$. This study found that the more frequent the seizures, the cognitive level will be lower. Frequent spontaneous seizures that occur can change sinaps plasticity that contribute to learning disorders and behavior. In epilepsy patient, often decreased in memory function and psychomotor responses [9]. This study result was similar with previous study. Poor seizure control and high frequency of seizure causes permanent cognitive impairment.

Research in secondary generalized seizure epilepsy found frequency of seizure $<10$ times got normal IQ test results. Otherwise in frequency of seizure $>50$ times got abnormal IQ test result $[10,13]$. Seizure can interfere with learning mechanism and memory in the brain. This process through the mechanism of inhibition and acquisition of maturity function. Previous study found that children who had drug resistance at 0-3 years old showed impaired cognitive function. This study is in accordance with previous study where the onset of epilepsy started in early life, if the frequency of seizures lesser then the disruption of cognitive function would be minimal $[11,15]$.

Frequency of seizure in this study affect the level of cognitive development $43.3 \%$, and $56.7 \%$ comes from another factors. Further research is needed to determine factors that influence the level of cognitive development in patient with drug resistant epilepsy.

\section{Conclusion and Suggestion}

This study shows that the frequency of seizures more than 10 times has a positive correlation with the level of cognitive development in children with drug-resistant epilepsy. A positive correlation between the frequency of seizures more than 10 times to the level of cognitive development in children with drug-resistant epilepsy indicates the need for seizure management quickly and appropriately. Proper and good management of seizures will affect the frequency or duration of seizures and reduce the risk of impaired cognitive function.

This study can be used as a baseline to conduct further studies that prove other factors related to the cognitive level of children with drug-resistant epilepsy.

\section{Disclosure}

The authors hereby declare no personal or professional conflicts of interest regarding any aspect of this study.

\section{References}

[1] Thompson PJ, Duncan JS. Cognitive Decline in Severe Intractable Epilepsy. Pubmed. Epilepsia. 2005; 40 (11): 1780-7.

[2] Vingerhoets G. Cognitive effects of seizures. Seizure. 2006; 15: 221-226.

[3] Mullen EM. General Administration and Scoring Procedures in Mullen EM: Mullen Scales of Early Learning AGS edition Manual. American Guidance Service Inc. 1995; 19-31.

[4] Kurniawati. Correlation between cognitive development with epilepsy in children 6-68 months age. Medicina. 2015.

[5] Suwarba IGNM. Insidens and characteristics of epilepsy in pediatric patients. Sari Pediatri. 2011; 13: 123-8.

[6] Y Camfield PR, Camfield CS. Pediatric Epilepsy: an overview. In Swaiman KF, Ashwal S, Ferriero DM, Schor NF. Swaiman's pediatric neurology principles and practice. $5^{\text {th }}$ edition. USA: Elsevier Saunders. 2005; 706-710.

[7] Hermann B, Seidenberg M. Epilepsy and cognition. Epilepsi Currents. 2007; 7: 1-6.

[8] Kayal A. Molecular Mechanisms of Cognitive and Behavioural Comorbidities of Epilepsy in Children. Epilepsia. 2011; 52 (Suppl. 1): 13-20.

[9] You SJ. Cognitive function of idiopathic childhood epilepsy. Korean J Pediatr. 2012; 55: 159-63.

[10] Aldenkamp AP, Bodde N. Behavior, Cognition and Epilepsy. Acta Neurol Scan. 2005; 11 (1): 19-25. 
[11] Berg AT, Loddenkemper T, Bacca CB. Diagnostic delays in children with early-onset epilepsy: impact, reasons, and opportunities to improve care. Epilepsia. 2005; 55: 123-32.

[12] Lodhi, S, Agrawal, N., 2012. Neurocognitive problems in epilepsi. Advances in psychiatric treatment, 18: 232-40.

[13] Vijayaraghavan, L., Natarajan, S., Krishnamoorthy, E. S. 2011. Peri-ictal and Ictal Cognitive Dysfunction in Epilepsi. Behavior Neurology, 24: 27-34.
[14] Berg, A. T., Loddenkemper, T., Bacca, C. B. 2014. Diagnostic delays in children with early-onset epilepsy: impact, reasons, and opportunities to improve care. Epilepsia, 55: 123-32.

[15] Camfield, P. R., Camfield, C. S. 2012. Pediatric Epilepsy: an overview. In Swaiman, K. F., Ashwal, S., Ferriero, D. M., Schor, N. F. Swaiman's pediatric neurology principles and practice. $5^{\text {th }}$ edition. USA: Elsevier Saunders.: 706-710. 